\title{
COMPARATIVE STUDY OF CAESAREAN SECTION BETWEEN CONVENTIONAL AND MISGAV-LADACH METHOD
}

\author{
Subhi Vithal', Vandana Rai ${ }^{2}$
}

${ }^{1}$ Assistant Professor, Department of Obstetrics and Gynaecology, Rama Medical College, Kanpur. ${ }^{2}$ Consultant, Department of Obstetrics and Gynaecology, Vidya Hospital, Azamgarh.

\begin{tabular}{l}
\hline ABSTRACT \\
BACKGROUND \\
Ever since the inception of caesarean section, this particular surgery had been innovated and re-innovated to provide better results \\
and decrease the mortality rates as well as post-operative morbidity rates. This study is to determine a clear advantage of Misgav- \\
Ladach method, over conventional caesarean section. Our study was non randomized controlled trial study, designed to determine \\
the prospects of Misgav-Ladach method over conventional caesarean section; Hence, every patient's retrospective analysis, pre- \\
operative and post-operative important parameters were being compared. The statistic applied was simple comparison between \\
group A (caesarean section) and group B (Misgav-Ladach method) on different assessing parameters.
\end{tabular}

\section{MATERIALS AND METHODS}

This non randomized controlled trial study was conducted in Department of OBG-GYN in Rama Medical College Hospital and Research Centre. Sample size was 50 in each group. Group A and Group B, each consisting fifty patients; Group A included fifty women to whom conservative lower segment caesarean section was performed. Group B consisted fifty women two whom caesarean section was performed by Misgav-Ladach method. Patients with previous caesarean section were excluded. Both the groups were compared on different parameters like extraction time, operation duration, mode of delivery, etc.

Data was analysed in SPSS version 16.0 (Statistical Package for Social Science).

\section{RESULTS}

There was significant reduction in operating time, including extraction time in group B. There was no significant difference in terms of febrile morbidity, but rate of wound sepsis and wound dehiscence were significantly low in group B. Short hospital stay, early enteral feeding, lesser analgesia were noted in group B. The results of this study were highly encouraging.

\section{CONCLUSION}

This study makes a lucid indication over superiority of Misgav-Ladach method over the conventional method of caesarean section. Though some parameters studied in this study were more or less same in both methods, there was improvement in extraction time, operation duration, wound sepsis, wound dehiscence, hospital stay, enteral feeding, analgesia, etc. in Misgav-Ladach method. Our study yielded highly encouraging results comparable with other studies. Further studies should be carried out on much larger sample of patients for a more lucid and exact conclusion.

\section{KEYWORDS}

Misgav-Ladach Method, Caesarean Section, Joel-Cohen Incision, Febrile Morbidity, Foetal Injury.

HOW TO CITE THIS ARTICLE: Vithal S, Rai V. Comparative study of caesarean section between conventional and Misgav-Ladach method. J. Evolution Med. Dent. Sci. 2017;6(89):6246-6252, DOI: 10.14260/jemds/2017/1358

\section{BACKGROUND}

Caesarean section is the most common major operation in the Obstetrics which is performed more as an emergency rather than an elective procedure. It has almost replaced mid-cavity forceps and other difficult vaginal deliveries. The incident is around $15-20 \%$ in most of the centres with mortality rate of $<1 \%$. But morbidity has still scope for reduction. Obstetricians usually innovate certain techniques while performing caesarean section leading to differences in the outcome. $(1,2,3,4)$

'Financial or Other Competing Interest': None.

Submission 24-02-2017, Peer Review 31-10-2017,

Acceptance 07-11-2017, Published 13-11-2017.

Corresponding Author:

Subhi Vithal,

17/455, Shastri Nagar,

Near Kali Mathiya Mandir,

Kanpur, U. P.

E-mail: subhivaryani224@gmail.com

DOI: $10.14260 /$ jemds $/ 2017 / 1358$

\section{(c) $(1)$}

There has been a substantial rise in the rate of caesarean section in last 20 years. There are many reasons for this increase but it has been urged that a fall in the perinatal mortality justifies a higher caesarean section rate. The reason for this increase are many. Availability of more efficient foetal monitoring with better understanding of foetal physiology have resulted in a more active management of pregnancy and labour. In the past, caesarean section was kept in reserve for those situations where a mother's life was to be saved, discounting the foetus. With improved anaesthesia and perioperative monitoring facilities, efficacious antibiotics, there has been a broadening of the scope of indication for its employment. Nowadays caesarean section is being performed in those cases where further delay in delivery may jeopardise the life of the foetus and or of the mother and safe vaginal delivery is not possible.[5,6]

Ever since the first caesarean section was performed, countless variations have been introduced at different steps of caesarean section with their own advantage and disadvantage. 


\section{Abdominal Opening}

Abdomen can be opened by either vertical or transverse incision. In transverse incision, some prefer to open by Pfannenstiel incision whereas others open by modified JoelCohen's incision.(7)

\section{Uterine Incision}

Now standard method of opening is by lower segment transverse incision. This is done either by blunt expansion method or by sharp outing technique. In case of difficulty in delivering baby, the transverse incision should be extended in a 'J' shaped fashion which is preferable to inverted ' $\mathrm{T}$ ' incision.

\section{Placental Delivery}

Sometimes manual removal of placenta is required.

\section{Repair of Uterus}

Uterus is closed conventionally in two layers whereas some do it in a single layer with continuous, non-locking or locking sutures.

\section{Suture Material}

Delayed absorbable suture, Vicryl is used for uterine closure, but conventionally chromic catgut is also used by some.

\section{Peritoneal Closure}

Some people stitch the peritoneum and some leave it open.

\section{Oxytocics}

There are variations in the dose of oxytocics used during surgery, some use it routinely in postoperative period and some use it as and when required.

\section{Antibiotics \\ Some use short-term (single dose or three doses) prophylactic antibiotic whereas others use 7 days routinely. ${ }^{(8,9)}$}

\section{Fluid Therapy}

Some start early oral; feeding with IV fluid for long duration. $(8,9,10,11,12)$

\section{Description of Conventional Caesarean Section}

Conventional caesarean section incision is the method of choice in many hospitals. It is a suprasymphyseal, low transverse (semilunar) incision with extreme ends gently curving upwards towards the anterior superior iliac crests just above the public symphysis or midline vertical incision. The method includes sharp dissection of the subcutaneous layer and the anterior rectus sheath. After separating the two recti in midline, the parietal peritoneum is incised vertically. A lower uterine segment transverse incision is performed as described by Kerr in 1926. After the baby is born, placenta is generally removed by insertion of obstetrician's hand and the incision is sutured in two separate layers. In addition to the fascia, the visceral and parietal layers, as well as subcutaneous layer are usually suturing techniques, such as staples, continuous intracutaneous suture or single sutures are used for skin closure.(10)
Description of the Misgav-Ladach Method (ML method) for Caesarean Section

This method is restrictive in the use of sharp instruments, preferring manipulation.

This is based on the Joel-Cohen incision originally introduced for hysterectomy. The modified Joel-Cohen is a straight transverse incision made $3 \mathrm{~cm}$ above the symphysis, the subcutaneous tissue is left undisturbed apart from the midline. Anterior rectus sheath is incised in the midline for 3 $\mathrm{cm}$ and then stretched with one index finger of each hand. The rectus muscles are separated by pulling. The parietal peritoneum is opened by stretching with index finger transversely without separating muscle from the sheath. A 3 $\mathrm{cm}$ transverse incision is given in the lower segment to penetrate most of the myometrial layer sharply sparing the deepest fibres which are subsequently opened with the blunt end of the scalpel to avoid foetal injury. The incision is then extended laterally with the help of index finger of one hand and thumb of the other hand. After delivery of the baby, the placenta is allowed to separate spontaneously followed by uterine closure with a one layer continuous locking stitch. The visceral and parietal peritoneal layers are left open. The rectus muscle is not stitched. The rectus sheath is stitched with a continuous non-locking stitch starting from right side of the wound proceeding to left skin, closed with 2 or 3 mattress sutures. In between space is pressed by blunt instrument for five min. then left as such.(13,14)

This non randomized controlled trial study was designed to know which of the two techniques i.e. the conventional caesarean section or caesarean section by Misgav-Ladach is better in terms of foetal and maternal outcome. $(14,15,16)$

\section{Aims and Objectives}

To compare conventional caesarean section by midline vertical method with Misgav-Ladach method.

\section{Parameters Compared Intra-operative \\ - Duration of surgery- \\ - Extraction time \\ - Total time \\ Post-operative \\ - Complications- \\ - Febrile morbidity. \\ - UTI. \\ - Wound sepsis. \\ - Wound dehiscence.}

- Time to ambulation.

- Hospital stay.

- Start of enteral feeding.

- Analgesic requirement.

\section{MATERIALS AND METHODS}

This study was an non randomized controlled trial study. This study was conducted on Women admitted in the Dept. of OBGYN in Rama Medical College Hospital \&Research Centre, Mandhana Kanpur from July 2012 to Sept. 2013, who had undergone caesarean section for various indications. Sample size was 50 in each group. Sample size was taken 
conveniently. Patients among those who admitted for delivery (Normal or Caesarean) were selected.

Group A consisted of 50 women $(n=50)$ in whom lower segment caesarean section was performed by conventional method i.e. opening the abdomen by midline vertical incision and closure achieved in multiple layers.

Group B consisted of 50 women ( $=50)$, in whom caesarean section was performed by Misgav-Ladach method i.e., opening the abdomen by modified Joel-Cohen technique and closing in a single layer.

Patients with previous caesarean section were not included in this study.

All the relevant information regarding Patient's identity, detailed history including gestational age, parity, relevant antenatal history, detailed obstetric history and menstrual history were recorded as per the proforma attached (Appendix - I) and analysed. Details of general physical examination including pallor, icterus, oedema, blood pressure were recorded. Breast examination was done in all cases, systemic examination included respiratory system, cardiovascular system and central nervous system in brief. Local examination of the abdomen was done in detail including fundal height, abdominal girth, lie, engagement of the presenting part, uterine contraction and foetal heart sound were noted. Per speculum examination was performed in cased of PV leaking and antepartum haemorrhage, per vaginal examination was done to note the cervical dilation, effacement, station of the presenting part and membrane, Pelvic assessment was done as per requirement,

Relevant antenatal investigation including blood group, $\mathrm{Hb} \%$, urine $\mathrm{R} / \mathrm{M}$ and urine $\mathrm{C} / \mathrm{S}$ (if indicated), liver function test, urine albumin, 4-hour urinary protein, Serum uric acid, electrolytes, creatinine, fundoscopy (if required) were recorded. $\mathrm{Hb} \%$ on post-operative day 2 was also recorded.

Operative details including extraction time and total duration of operation were recorded.

Extraction time was the duration from skin incision to clamping of the umbilical cord, and the total duration of operation was the time taken from skin incision to skin closure.

Mode of delivery of baby was by vertex presentation or by breech extraction. Any difficulty during delivery of baby, deliberate or spontaneous extension of the uterine incision in the form of 'J' were noted. Details about the baby i.e. sex, weight, time of delivery, live/IUD/stillbirth were recorded.

Method of placental removal and any calcification or retroplacental clot was noted. Details about the layers of closure and suture material used were recorded.

During post-operative period, analgesic requirement, time to ambulation and start of enteral feeding were recorded. Febrile morbidity, wound sepsis and urinary tract infection was noted in both groups. Febrile morbidity was defined by a temp of $>100.40 \mathrm{~F}$ on post-operative day 2 onwards. Wound sepsis was defined by presence of purulent of seropurulent discharge $+/$ - culture positivity. UTI included women with their urine $\mathrm{R} / \mathrm{M}$ showing $>5$ pus cells/hpf irrespective of culture report.
Hospital stay was recorded from the day of operation to the day of discharge.

\section{Exclusion Criteria}

Any women with history of previous caesarean section were excluded from the study.

\section{Statistical analysis}

All the data obtained was analysed using SPSS version 16.0, was entered in MS- excel spread sheet. Chi-square test was used to compare the difference in proportion in the two groups. Student's ' $t$ ' test was performed to see the difference between mean of two groups.

\section{RESULTS}

This study gave a clear leverage to Misgav-Ladach method over conventional method of caesarean section. Out of different parameters compared, extraction time, operation duration, hospital stay, start of enteral feeding, wound sepsis, wound dehiscence, analgesia, etc. gave promising results favouring Misgav-Ladach approach for caesarean section. The other parameters compared yielded more or less same results for both approaches.

The results of our study were highly encouraging and comparable with other studies. This study should be done on higher number of patients, to decipher a marked superiority of Misgav-Ladach method over conventional method for caesarean section.

\begin{tabular}{|c|c|c|c|c|}
\hline Variables & $\begin{array}{c}\text { Group A } \\
(\mathbf{n = 5 0 )}\end{array}$ & $\begin{array}{c}\text { Group } \\
\mathbf{B ( n = 5 0 )}\end{array}$ & $\begin{array}{c}\mathbf{x}^{\mathbf{2}} \\
\text { value }\end{array}$ & “P”Value \\
\hline Age & $25.39 \pm 4.15$ & $24.90 \pm 4.29$ & & \\
\hline \multicolumn{5}{|c|}{ Parity } \\
\hline Primi & $14 \pm 28$ & $12 \pm 24$ & 0.0208 & 0.648 \\
\hline Multi & $36 \pm 72$ & $38 \pm 76$ & 0.0210 & 0.0651 \\
\hline \multicolumn{5}{|c|}{ Gestational Age } \\
\hline $\begin{array}{c}\text { Preterm } \\
(<37 \text { weeks })\end{array}$ & $6 \pm 12$ & $3 \pm 6$ & 1.099 & 0.295 \\
\hline $\begin{array}{c}\text { Term } \\
(37-42 \text { weeks) }\end{array}$ & $44 \pm 88$ & $47 \pm 94$ & 1.101 & 0.298 \\
\hline \multicolumn{5}{|c|}{ Table 1. Characteristics } \\
\hline
\end{tabular}

Table 1 shows the characteristics of two groups. The mean age in two groups was $25.39 \pm 4.15$ Years (group A) and $24.90 \pm 4.29$ Years (group B) respectively, thus showing no statistically significant difference between the two groups,

Majority of subjects were multiparous in both the groups, only $14(28 \%)$ of group A and 12 (24\%) of group B subjects were primiparous. Statistically, there was no significant difference between the two groups ( $\mathrm{p}=0.648)$.

There were 44 (88\%) of group A and 47 (94\%) of group B subjects who had a gestational age ranging between $37-42$ weeks. Thought the proportion of term cases was slightly higher in study, it was not significant statistically ( $p=0.295)$.

Thus, the two groups under study i.e. Group A and Group B were matched statistically and there was no significant difference between the two groups with regards to age, parity and gestational age. 


\begin{tabular}{|c|c|c|c|c|c|c|}
\hline Foetal Distress & 10 & 20 & 18 & 36 & 3.175 & 0.075 \\
\hline CPD & 10 & 20 & 4 & 8 & 2.990 & 0.084 \\
\hline $\begin{array}{c}\text { Breech } \\
\text { presentation }\end{array}$ & 6 & 12 & 8 & 16 & 0.332 & 0.564 \\
\hline Transverse lie & 4 & 8 & 4 & 8 & 0 & 1 \\
\hline APH & 5 & 10 & 1 & 2 & 2.837 & 0.092 \\
\hline PIH & 2 & 4 & 3 & 6 & 0.211 & 0.646 \\
\hline $\begin{array}{c}\text { Deep transverse } \\
\text { arrest }\end{array}$ & 1 & 2 & 0 & 0 & - & - \\
\hline $\begin{array}{c}\text { Meconium-stained } \\
\text { liquor }\end{array}$ & 12 & 24 & 12 & 24 & 0 & 1 \\
\hline Table 2. Indication of Caesarean Section \\
\hline
\end{tabular}

Table 2 shows overall indication of caesarean section among both groups. In conventional group, Meconiumstained liquor was the most common indication for caesarean section while in group B foetal distress was the most common indication for caesarean section. Overall foetal distress was the most common indication. Amongst other common indications, Meconium-stained liquor CPD, breech presentation were more common indications while transverse lie, APH, PIH and deep transverse arrest were the less common indications. Statistically there was no significant difference between the two groups in the indication of caesarean section $(\mathrm{p}>0.05)$.

\begin{tabular}{|c|c|c|c|c|c|c|}
\hline \multirow{2}{*}{ Nature } & \multicolumn{2}{|c|}{$\begin{array}{c}\text { Group A } \\
(\mathbf{n = 5 0}\end{array}$} & \multicolumn{2}{c|}{$\begin{array}{c}\text { Group B } \\
(\mathbf{n = 5 0}\end{array}$} & \multirow{2}{*}{$\begin{array}{c}\mathbf{X}^{2} \\
\text { Value }\end{array}$} & $\begin{array}{c}\text { 'p' } \\
\text { Value }\end{array}$ \\
\cline { 2 - 5 } & $\mathbf{n}$ & $\mathbf{\%}$ & $\mathbf{n}$ & $\mathbf{\%}$ & & \\
\hline Emergency & 44 & 88 & 42 & 84 & 0.3322 & 0.564 \\
\hline Elective & 6 & 12 & 8 & 16 & 0.102 & 0.749 \\
\hline \multicolumn{6}{|c|}{ Table 3. Nature of Caesarean Section } \\
\hline
\end{tabular}

Table 3 shows nature of caesarean section. In group A, 44 (88.00\%) were emergency caesarean sections and 6 $(12.00 \%)$ were elective whereas in group B $42(84.00 \%)$ were emergency caesarean sections and $8(16.00 \%)$ were elective.

Statistically there was no significant difference between the two groups.

\begin{tabular}{|c|c|c|c|c|}
\hline Duration & $\begin{array}{c}\text { Group A } \\
(\mathbf{n = 5 0 )}\end{array}$ & $\begin{array}{c}\text { Group } \\
\mathbf{B}(\mathbf{n}=\mathbf{5 0})\end{array}$ & $\mathbf{X}^{\mathbf{2}^{\prime} \text { Value }}$ & 'p'Value \\
\hline $\begin{array}{c}\text { Extraction } \\
\text { time }\end{array}$ & $5.10 \pm 1.29$ & $3.77 \pm 0.82$ & 6.153 & $<0.001$ \\
\hline $\begin{array}{c}\text { Total } \\
\text { duration }\end{array}$ & $34.58 \pm 5.16$ & $27.05 \pm 3.56$ & 8.494 & $<0.001$ \\
\hline \multicolumn{4}{|c|}{ Table 4. Duration of Caesarean Section } \\
\hline
\end{tabular}

Table 4 shows operative characteristics. Mean extraction time in group A was $5.10 \pm 1.29 \mathrm{~min}$. whereas total duration of operation was $34.58 \pm 5.16 \mathrm{~min}$. In group $\mathrm{B}$, mean extraction time was $3.77 \pm 0.82 \mathrm{~min}$. whereas mean duration of operation was $27.05 \pm 3.56 \mathrm{~min}$. Both extraction time and total duration of operation was significantly lower in group $B$ as compared to group A $(\mathrm{p}<0.001) \cdot(17,18)$

\begin{tabular}{|c|c|c|c|c|c|c|}
\hline \multirow{2}{*}{ Complication } & \multicolumn{2}{|c|}{$\begin{array}{c}\text { Group A } \\
(\mathbf{n = 5 0 )}\end{array}$} & \multicolumn{2}{c|}{$\begin{array}{c}\text { Group B } \\
\mathbf{( n = 5 0 )}\end{array}$} & \multirow{2}{*}{$\begin{array}{c}\mathbf{X}^{2} \\
\text { Value }\end{array}$} & $\begin{array}{c}\text { 'p' } \\
\text { Value }\end{array}$ \\
\cline { 2 - 6 } & $\mathbf{n}$ & $\mathbf{\%}$ & $\mathbf{n}$ & $\mathbf{\%}$ & & \\
\hline $\begin{array}{c}\text { Febrile } \\
\text { morbidity }\end{array}$ & 8 & 16 & 7 & 14 & 0.078 & 0.779 \\
\hline Wound sepsis & 8 & 16 & 2 & 4 & 2.700 & $<0.01$ \\
\hline UTI & 7 & 14 & 6 & 12 & 0.088 & 0.766 \\
\hline $\begin{array}{c}\text { Wound } \\
\text { dehiscence }\end{array}$ & 5 & 10 & 0 & 0 & 1.98 & $<0.05$ \\
\hline
\end{tabular}

Table 5. Post-operative Complications

Table 5 shows the postoperative complications: febrile morbidity, wound sepsis, wound dehiscence and UTI.

Febrile morbidity was observed in 8 cases $(16.00 \%)$ of patients in group A as compared to 7 cases $(14.00 \%)$ in group B. Wound sepsis and wound dehiscence was present in 8 cases $(16.00 \%)$ and 5 cases $(10.00 \%)$ respectively of group A as compared to 4 cases $(8.00 \%)$ or wound sepsis in group B. None of the women in group B had wound dehiscence. ${ }^{(18,19)}$

UTI was present in 7 cases $(14.00 \%)$ in group A as compared to 6 cases (12.00\%) in group B.

For none of the above variables a statistically significant difference between two groups could be seen ( $p>0.05)$.

\begin{tabular}{|c|c|c|c|c|c|c|}
\hline \multirow{2}{*}{$\begin{array}{c}\text { Duration } \\
\text { (days) }\end{array}$} & \multicolumn{2}{|c|}{$\begin{array}{c}\text { Group } \\
\mathrm{A}(\mathrm{n}=\mathbf{5 0})\end{array}$} & \multicolumn{2}{|c|}{$\begin{array}{c}\text { Group } \\
B(n=50)\end{array}$} & \multirow{2}{*}{$\begin{array}{c}\mathrm{X} 2 \\
\text { Value }\end{array}$} & \multirow{2}{*}{$\begin{array}{c}\text { 'p' } \\
\text { Value }\end{array}$} \\
\hline & $\mathbf{n}$ & $\%$ & $\mathrm{n}$ & $\%$ & & \\
\hline$<7$ days & 15 & 30 & 32 & 64 & 0.078 & 0.779 \\
\hline $\begin{array}{c}>7 \\
\text { days }\end{array}$ & 35 & 70 & 18 & 36 & 0.078 & 0.779 \\
\hline $\begin{array}{c}\text { Mean } \\
\text { stay }\end{array}$ & & $\begin{array}{c}6.92 \pm \\
3.57\end{array}$ & & $\begin{array}{l}5.06 \\
\pm 1.23 \\
\end{array}$ & 3.383 & 0.001 \\
\hline \multicolumn{7}{|c|}{ Table 6. Hospital Stay } \\
\hline
\end{tabular}

Table 6 shows hospital stay of the patient. Those staying < 7 days were $15(30.00 \%)$ and $32(64.00 \%)$ in Group A and Group B respectively. 35 women (70.00\%) among group A stayed for $>7$ days as compared to $18(36.00 \%)$ in group B. $(20,21)$

Average duration of hospital stay was 6.92 c3.57 days and $5.06 \pm 1.23$ days respectively for Group A and Group B $(\mathrm{p}<0.001)$.

In group A the hospital stay was significantly higher as compared to that in group $B(\mathrm{p}<0.001)$.

In terms of mean hospital stay too, the mean duration of stay in group A $(6.23 \pm 3.57$ days) was significantly higher as compared to that in group B $(5.06 \pm 1.23$ days $)(p<0.001)$.

\begin{tabular}{|c|c|c|c|c|c|c|}
\hline \multirow[t]{2}{*}{ Duration } & \multicolumn{2}{|c|}{$\begin{array}{c}\text { Group A } \\
(n=50)\end{array}$} & \multicolumn{2}{|c|}{$\begin{array}{c}\text { Group } \\
B(n=50)\end{array}$} & \multirow{2}{*}{$\begin{array}{c}\mathrm{X}^{2} \\
\text { Value }\end{array}$} & \multirow{2}{*}{$\begin{array}{c}\text { 'p' } \\
\text { Value }\end{array}$} \\
\hline & $\mathrm{n}$ & $\%$ & $\mathbf{N}$ & $\%$ & & \\
\hline$<24$ hrs. & 15 & 30 & 39 & 78 & 23.188 & $<0.001$ \\
\hline$>24$ hrs. & 35 & 70 & 11 & 22 & 23.188 & $<0.001$ \\
\hline $\begin{array}{c}\text { Mean } \\
\text { time(hrs.) }\end{array}$ & & $\begin{array}{c}42 \\
\pm 10\end{array}$ & & $30 \pm 8$ & 6.626 & 0.001 \\
\hline
\end{tabular}

Table 7 shows time duration to start the enteral feeding after surgery. In group A, the enteral feeding could be started within 36 hours in only $15(30 \%)$ of the subjects whereas in Group B this proportion was 78\% (n=39), significantly higher as compared to group $A(p<0.001)$. 
As mean time to feeding was concerned, it was $42 \pm 10$ hrs. in group A which was significantly higher as compared to $30 \pm 8$ hrs. as observed in group $\mathrm{B}(\mathrm{p}<0.001)$.

\begin{tabular}{|c|c|c|c|c|c|c|}
\hline \multirow[t]{2}{*}{ Duration } & \multicolumn{2}{|c|}{$\begin{array}{c}\text { Group } \\
\mathbf{A}(\mathrm{n}=\mathbf{5 0})\end{array}$} & \multicolumn{2}{|c|}{$\begin{array}{c}\text { Group B } \\
(n=50)\end{array}$} & \multirow{2}{*}{$\begin{array}{c}\mathrm{X}^{2} \\
\text { Value }\end{array}$} & \multirow{2}{*}{$\begin{array}{c}\text { 'p' } \\
\text { Value }\end{array}$} \\
\hline & $\mathbf{N}$ & $\%$ & $\mathbf{n}$ & $\%$ & & \\
\hline$<36$ hrs. & 12 & 24 & 41 & 82 & 33.762 & $<0.001$ \\
\hline$>36 \mathrm{hrs}$ & 38 & 76 & 9 & 18 & 33.762 & $<0.001$ \\
\hline $\begin{array}{c}\text { Mean } \\
\text { time(hrs.) }\end{array}$ & & $38 \pm 8$ & & $27 \pm 4$ & 8.696 & 0.001 \\
\hline \multicolumn{7}{|c|}{ Table 8. Time to Ambulation } \\
\hline
\end{tabular}

In group A, only 12 (24\%) patients could ambulate within $36 \mathrm{hrs}$. of surgery whereas in group B 41 (82\%) patients could ambulate within 36 hrs. of surgery. Thus, in group B significantly higher proportion of patients could ambulate early as compared to group A $(\mathrm{p}<0.001)$

As regards to the mean time to ambulation, it was $38 \pm 8$ hrs. in group A which was significantly higher $(\mathrm{p}<0.001)$ when compared to group $B$ which had a mean time to ambulation of $27 \pm 4$ hrs.

NSAIDs were used in all the patients in both the groups, thus showing no statistically significant difference between the two $(p=1)$. However, NSAIDs in combination with Opioids were used more frequently (46\%) in group $A$ as compared to group B (24\%), thus showing a significant difference between the two groups $(\mathrm{p}=0.021) \cdot(21,22)$

\section{DISCUSSION}

The study was non randomized controlled trial study carried out in the Dept. of OB-GYN, Rama Medical College Hospital \& Trauma Centre, Mandhana, Kanpur comprising of 50 women in each group. Group A(caesarean section by midline conventional method) and Group B (caesarean section by Misgav-Ladach method). The important aspects considered were operating time (including extraction time), Postoperative complications (febrile morbidity, wound sepsis, UTI, wound dehiscence), hospital stay, time to start enteral feeding, time to ambulation and requirement of analgesia.

\begin{tabular}{|c|c|c|}
\hline Study & Group A & Group B \\
\hline Franchi M et al (2002) & $4 \mathrm{~min}$. & $3 \mathrm{~min} .10 \mathrm{sec}$. \\
\hline Moriera P et al (2002) & $5 \mathrm{~min} .20 \mathrm{sec}$. & $5 \mathrm{~min} .26 \mathrm{sec}$. \\
\hline Studzinski Z et al $(2002)$ & $3 \mathrm{~min} .42 \mathrm{sec}$. & $1 \mathrm{~min} .6 \mathrm{sec}$. \\
\hline Present study & $5.10 \pm 1.29 \mathrm{~min}$ & $3.77 \pm 0.82 \mathrm{~min}$ \\
\hline
\end{tabular}

Mean Total Operating Time

\begin{tabular}{|c|c|c|}
\hline Study & Group A & Group B \\
\hline Bjorklun et al (2002) & $32 \pm 02 \mathrm{~min}$. & $25 \pm 03 \mathrm{~min}$. \\
\hline Ferrari AG et al (2002) & $444 \pm 1.44 \mathrm{~min}$. & $31.6 \pm 1.38 \mathrm{~min}$. \\
\hline Moriera P et al (2002) & $54 \mathrm{~min} .38 \mathrm{sec}$. & $36 \mathrm{~min} .36 \mathrm{sec}$. \\
\hline Ohel G et al (1996) & $44.4 \pm 16 \mathrm{~min}$. & $32 \pm 11 \mathrm{~min}$. \\
\hline Redocj A et al (2001) & $49 \mathrm{~min} .18 \mathrm{sec}$. & $29 \mathrm{~min} .48 \mathrm{sec}$. \\
\hline Wallin G et al (1999) & $28 \mathrm{~min}$. & $20 \mathrm{~min}$. \\
\hline Present study & $\begin{array}{c}34.58 . \pm 5.16 \\
\text { min. }\end{array}$ & $27.50 \pm 3.56 \mathrm{~min}$. \\
\hline \multicolumn{3}{|c}{} \\
\hline \multicolumn{2}{|c}{}
\end{tabular}

There was significantly reduced operating time including the extraction time in group B. In our study, the mean operating time was $27.05 \pm 3.56 \mathrm{~min}$. and the extraction time was $3.77 \pm 0.82 \mathrm{~min}$. for the group B whereas it was $34.58 \pm$ $5.16 \mathrm{~min}$. and $5.10 \pm 1.29 \mathrm{~min}$. for the Group $\mathrm{A}(\mathrm{p}<0.001)$ respectively (Table 4). Our mean operating time by two methods was less than the study of Wallin $G$ in which median operating time was $20 \mathrm{~min}$. in modified Joel-Cohen group and 28 min. in Pfannenstiel group. In our study, the extraction time and mean operating time were significantly shorter as compared to Moreira P et al study who found extraction time of $5 \mathrm{~min}$. $26 \mathrm{sec}$. vs. $6 \mathrm{~min}$. $20 \mathrm{sec}$. and mean operating time of $36 \mathrm{~min} .36 \mathrm{sec}$. vs. $54 \mathrm{~min} .38 \mathrm{sec}$. for the two methods.

Franchi $M$ found no significant difference in mean operating time by two methods ( $32 \mathrm{~min}$. vs. $33 \mathrm{~min}$.) whereas extraction time was significantly shorter in Joel-Cohen group than in Pfannenstiel group (190 sec. vs. $240 \mathrm{sec}$. $\mathrm{P}=0.05)$ Significant increase in extraction time by tying the bleeders prior to delivery of baby which is not needed in Joel-Cohen method of opening the abdomen.

Farrari AG also found significant difference in operating time by two methods $(31.6 \pm 1.44 \mathrm{~min}$.). In this study, operating time was higher than our study and it was also higher in Ohel G Study (32 min. \pm 11 min. vs. $44+16$ $\min$.).

Similarly, Studzinski Z also found significantly different operating time (20.2 min vs. 47.3). Their extraction time was significantly less as compared to our study in both groups (1.1 min. and $3.77 \mathrm{~min}$. respectively as compared to $3.7 \mathrm{~min}$. and $5.10 \mathrm{~min}$.). Similarly, Enkin MW and Grundsell HS also found a shorter operating time by $5.6 \mathrm{~min}$ and 7.9 min respectively by two techniques which is comparable to our study.(22,23)

We found that there is no significant difference in terms of febrile morbidity (16.00\% in group A vs. $14.00 \%$ in group B, $\mathrm{p}=\mathrm{Ns})$ and UTI (14.00 \% in group A vs. $12.00 \%$ in group $B, p+N S$ ) (Table 5). But rate of wound sepsis significantly occurred in 5 patients $10.00 \%$ ) in group A whereas none in group B) $(\mathrm{p}<0.05)$ (Table 5).

\section{Post-operative complications}

\begin{tabular}{|c|c|}
\hline Study & $\begin{array}{c}\text { Wound Infection in Study } \\
\text { Groups }\end{array}$ \\
\hline Bagratee J S et al (2001) & $3.4 \%$ \\
\hline Human S H et al. (1997) & $3 \%$ \\
\hline Ruiz et al. (1991) & $2 \%$ \\
\hline Hagglund L et al (1989) & $2.5 \%$ \\
\hline Present study & $4 \%$ \\
\hline
\end{tabular}

Our study is comparable to D' Angelo LJ who found no significant differences in febrile morbidity and UTI between the group B and group A. Regarding wound infection in group B, our study $(4.00 \%)$ is comparable to Bagratee JS et al (3.4\%) and to Huam SH et al (3\%). Our wound infection rate was high in group B as compared to Ruiz-Moremno JA (2\%), Hagglund L $(2.5 \%)$ and Spinatto JA (1.30\%) but was significantly low as compared to Bidi $\mathrm{M}$ et al (11\%) and Dimitrov 0 (6.89\%).

Post-operative hospital stay was noted from the day of surgery to the day of discharge. Hospital stay was $<7$ days in 15 patients $(30.00 \%)$ in the group $A$ and in 32 patients $(64.00 \%)$ in the group B and in 18 patients $(36.00 \%)$ in group 
B (Table 6). Mean hospital stay was $6.29 \pm 1.23$ days in group B. Group B patients had significantly shorter hospital stay. Winkler et al (1986) and Lankovet al (1999) also reported shorter hospital stay in single layer closure. However, in the study done by Paul et al (1999), hospital stay was same in both the groups. $(22,23,24)$

Enteral feeding was started at $<24$ hrs. in 15 patients $(30.00 \%)$ in group A and in 39 patients $(78.00 \%)$ in group B whereas at $>24$ hrs. in 35 patients $(70.00 \%)$ in group $A$ and in 11 patients $(22.00 \%)$ in group B (Table 7 ). In group B, mean time to start enteral feeding was $30 \pm 8 \mathrm{hrs}$. as compared to $42 \pm 10$ hrs. in group. Early return of bowel activity in group $B$ may be because of minimal bowel handling and shorter duration of surgery. However, Paul et al (1999) reported no significant difference between two groups.

12 patients $(24.00 \%)$ in group $A$ and in 41 patients $(82.00 \%)$ in study were made ambulatory at $<36 \mathrm{hrs}$. Whereas 38 patients $(76.00 \%)$ in the group A and 9 patients $(18.00 \%)$ in group B were made ambulatory at $<36 \mathrm{hrs}$. (Table 8). In group B mean time to ambulation was $27 \pm 4 \mathrm{hrs}$., the difference was statistically significant $(\mathrm{p}<0.001)$.

The group B required significantly lesser analgesia. Our study is supported by Refique $\mathrm{Z}$ et al (2002) who found that non-closure of peritoneum required significantly less analgesics.(25)

\section{CONCLUSION}

\section{The Conclusions derived from the above findings are-}

1. The mean operating time and extraction time is significantly shorter in group B as compared to group A.

2. Analgesic requirement is significantly less in group $B$ as compared to group A.

3. Early oral feeding is not associated with any gastrointestinal morbidity (i.e. abdominal distension, paralytic ileus, etc.). So it can be safely started 6-12 hrs. postoperatively.

4. Time to ambulation is significantly shorter in group B as compared to group A.

5. There is no significant difference in febrile morbidity or incidence of urinary tract infection in the two groups.

6. The incidence of wound sepsis is found to be significantly higher in group A.

7. Wound dehiscence is more in group A.

8. Mean hospital stay is significantly shorter in group B as compared to group A.

Hence, we conclude that the study technique of caesarean section is less time taking, cost effective, requires less analgesia with early ambulation and early start of enteral feeding resulting in quicker recovery and early discharge. Also uterus is easily palpable as against the vertical incision to ensure that it is contracted.

\section{REFERENCES}

[1] Rabbo AS. Early oral hydration: a novel regimen for management after elective caesarean section. J Obstet Gynaecol (Tokyo) 1995;21(6):563-7.

[2] Ansaloni L, Brundisini R, Morino G, et al. Prospective, randomized, comparative study of Misgav-Ladach versus traditional caesarean section at Nazareth Hospital, Kenya. World J Surg 2001;25(9):1164-72.
[3] Bagratee JS, Modley J, Kleinschmidt I,et al. A randomized controlled trial of prophylaxis in elective caesarean delivery. BJOG 2001;108(2):143-8.

[4] Beck AC. Observations on a series of cases of caesareans section done at the Long lsland college hospital during the past six years. Am J Obstet Gynecol 1919;79: p. 197.

[5] Bibi M, Megdiche $\mathrm{H}$, Ghahem $\mathrm{H}$, et al. Antibiotic Prophylaxis in a prior cesarean sections without a high risk of infection. Experiences of a Tunisian maternity department. J Gynecol Obstet Biol Reprod (Paris) 1994;23(4):451-5.

[6] Bjorklund K, Kimaro M, Urassa E, et al. Introduction of Misgav Ladach caesarean section at an African tertiary centre: a randomized controlled trial. BJOG 2000;107(2):209-16.

[7] Boyd ME. Caesarean section. Can J Surg 1988;31(1):10-3.

[8] Burrows WR, Gingo AJ, Rose SM, et al. Safety and efficacy of early postoperative solid food consumption after caesarean section. J Reprod Med 1995;40(6):463-7.

[9] D'Angelo LJ, SokolRJ. Short versus long course prophylactic antibiotic treatment in caesarean section patients. Obstet Gyneol 1980;55(5):583-6.

[10] De Lee JB, Cornell EL. Low cervical caesarean section (Laparotrachelotomy). JAMA 1922;79(2):109-12.

[11] Dimitrov 0, Katsarova M, KhadzhievKH, et al. The importance of the prophylactic use of antibiotic with women importance of the prophylactic use of antibiotic with women undergoing elective caesarean section. AkushGinekol (Sofiia) 1991;29(3):12-4.

[12] Duff P, Smith PN, Keiser JF. Antibiotic prophylaxis in low risk caesarean section. J Repod Med 1982;27(3):133-8.

[13] Eastman NJ. The role of frontier America in the development of caesarean section. Am J Obstet Gyvecol 1932;24: p. 919.

[14] Bujold E, Bujold C, Hamilton EF,et al. The impact of a single-layer closure or double-layer closure on uterine rupture. Am J Obstet Gynecol 2002;186(6):1326-30.

[15] Lobaton EJM, Hinojosa RDE, Kistner. Prophylactic use of antibiotics in caesarean section. Gynecol Obstet Max 1991;59(1):35-8.

[16] Ferrari AG, Frigerio LG, Caudotti G, et al. Can JoelCohen incision and single layer reconstruction reduce cesarean section morbidity? Int J Gynaecol Obstet, 2001;72(2):135-43.

[17] Franchi M, Ghezi F, Raio L, et al. Joel-Cohen or Pfannenstiel incision at caesarean delivery. Does it make a difference? Acta Obstet Gynecol Scand 2002;81(11):1040-6.

[18] Frank F. Suprasymphyseal delivery and its relation to other operation in the presence of contracted pelvis. Arch Gynaecol 1907;81: p. 46.

[19] Galaal KA, Krolikowski A. A randomized controlled study of peritoneal closure at caesarean section. Saudi Med J 2000;21(8):759-61.

[20] Gaucherand P, Bessai K, Sergeant P, et al. Towards simplified caesarean section? J Gynecol Obstet Biol Repord (Paris) 2001;30(4):348-52. 
[21] Giacalone PL, Daures JP, Vignal J, et al. Pfannenstiel versus Maylard incision for caesarean delivery: a randomized controlled trial. Obstet Gynecol 2002;99(5Pt 1):745-50.

[22] Grundsell HS, Rizk DE, Kumar RM. Randomized study of non-closure of peritoneum in lower segment caesarean section. Acta Obstet Gynecol Scand 1998;77(1):110-5.

[23] Guedj P, Eldor J, Stark M. Immediate postoperative oral hydration after caesarean section. Asia Oceania J Obstet Gynecol 1991;17(2):125-9.
[24] Hagglund L, Christensen KK, Christensen P, et al. Reduced rate of postoperative infections in emergency caesarean section after two doses of cefuroxime perioperatively. A placebo-controlled study. Acta Obstet Gynecol Scand 1989;68(3):201-4.

[25] Hauth JC, Owen J, Devis RO. Transverse uterine incision closure: one versus two layers. Am J Obstet Gynecol 1992;167(4 Pt 1):1108-11. 